Uşak Üniversitesi Sosyal Bilimler Dergisi

$2016,9 / 1$

\title{
Eğitim Fakültesi Öğrencilerinin Kişilerarası İlişki Tarzları ve Psikolojik Eğilimlerinin İncelenmesi
}

\author{
Erhan TUNÇ* \\ Yasemin KAYGAS**
}

\section{Öz}

$\mathrm{Bu}$ çalışmada üniversite öğrencilerinin psikolojik eğilimleri ve kişilerarası ilişki tarzları incelenmiştir. Araştırmanın evreni Gaziantep Üniversitesi Eğitim Fakültesi'nde öğrenim görmekte olan öğrencilerden oluşmaktadır. Araştırmanın örneklemi ise 2012-2013 eğitim-öğretim yılında Gaziantep Üniversitesi Eğitim Fakültesi Sınıf Öğretmenliği, İlköğretim Matematik Öğretmenliğii, Türkçe Öğretmenliği, Rehberlik ve Psikolojik Danışmanlık öğrenim görmekte olan 572 öğrenciden oluşmaktadır. Araştırmada veri toplamak amacıyla "Demografik Bilgi Formu", "Eysenck Kişilik Envanteri" ve "Kişilerarası İlişki Tarzları Ölçeği" kullanılmıştır. Verilerin analizinde betimsel istatistikler, t-testi ve ANOVA kullanılmıştır.

Araştırma sonucunda; "dışadönüklük" puan ortalamalarının kızlarda, annesini ve babasını demokratik algılayanlarda ve gelir düzeyini yüksek gelir düzeyinde algılayanlarda; "zehirleyici ilişki tarzı" puanlarının erkeklerde, Rehberlik ve Psikolojik Danışmanlık bölümü öğrencilerinde, babası okur-yazar olmayanlarda, 4.sınıf öğrencilerinde, gelir düzeyini yüksek gelir düzeyinde algılayanlarda ve annesini gevşek tutumlu olarak algılayan öğrencilerde; "nevrotizm" puan ortalamalarının Türkçe öğretmenliği öğrencilerinde ve annesini aşırı disiplinli algılayanlarda; "psikotizm" puan ortalamalarının 3. ve 4. sınıf öğrencilerinde, yüksek gelir düzeyinde algılayanlarda ve hem annesi hem babası üniversite mezunu olanlarda anlamlı derecede yüksek olduğu görülmüştür.

Anahtar Kelimeler: Kişiler Arası İlişki Tarzları, Bağlanma Stilleri, Psikolojik Eğilim

*Yrd. Doç. Dr., Gaziantep Üniversitesi, Eğitim Bilimleri Bölümü

** Psikolojik Danışman, Gaziantep Üniversitesi 


\title{
An Investigation of Educational Faculty Students' Interpersonal Relationship Styles and Psychological Tendencies
}

\begin{abstract}
In this study, interpersonal relations methods and psychological inclination of university students have been analyzed. The universe of the study contains students having education at the Faculty of Education at Gaziantep University. The sampling of the study consist of 572 students studying at Gaziantep University in the education year of 2012-2013 from departments of class teaching, primary school mathematics taeching, Turkish taeching, guidance and psychological counseling. Demografik information form, Eysenck Personal Inventory and interpersonal relations types measure have been used in order to collect data. For the analysis of the data, desciptive statistics, t-test and anova have been used.

As a result of the study, it has seen the "extraversion" point average are significantly high with the students perceiving their parents as democratic and from higher income level and poisonous relations style points are higher with males, students whose parents are ignorant, students ot senior grade, students from higher income group and students whose mothers have looser approach. "nevrotizm" points avareges are significantly higher at Turkish teaching students, student whose mothers are overdisciplined, and "psychotism" points avareges are higher at third graders and seniors, students from higher level of income and students with parents of both university graduates.
\end{abstract}

Keywords: Interpersonal Relations Methods, Attachment Styles, Psychological Inclination

\section{Giriş}

Kişilik; bir kişinin zaman içinde az veya çok durağan içsel faktörler biçiminde gösterdiği tutarlı davranışlardır ve bu davranışlar kıyaslanabilir durumlarda diğer insanlardan açıkça farklılık gösterir (Child, 1968).

Spielberger kişilik gibi sürekliliği olan özelliklerin çocukluk yıllarında geliştiğini ve yaşam boyunca kalıcı olduklarını hatırlatarak, ergenliğin başlarında hala kişilik özellikleri tamamen gelişmiş ve yerleşmiş değilken, öfkeyi azaltmaya yönelik müdahalelerin daha etkili olabileceğini ifade etmiştir (Mahon ve Diğ., 2000; akt: Yıldız 2009).

Psikolojide kişilik kapsamı en geniş olan kavramdır. Kişilik, bir insanın bütün ilgilerinin, tutumlarının, yeteneklerinin, konuşma tarzının, dış görünüşünün ve çevresine uyum biçiminin özelliklerini içeren bir 
Sosyal Bilimler Dergisi 55

terimdir. Bununla birlikte, kişilik kendine özgü ve ahenkli bir bütündür. Öyle ki, bir insana ilişkin her nitelik, o insanı anlamada bize ipucu verir. Onun belleği, dış görünüşü, direnme süreci, sesi ve konuşma tarzı, tepki hızı, insanlara, doğaya ya da makinelere karşı ilgi duyması, sporculuğu vb. özelliklerinin tümü o insanın kişiliğini betimleme de önemlidir (Yanbastı, 1990)

Literatür incelendiğinde araştırmacıların kişilik tanımlarının birbirilerinden farklılıklar gösterdiği gözlenmektedir. Cüceloğlu (1997) kişiliği, bireyin iç ve diş çevresiyle kurduğu diğer bireylerden ayırt edici, tutarlı ve yapılaşmış bir ilişki biçimi olarak açıklarken başka bir tanımda kişilik, bir insanın bütün ilgilerinin, tutumlarının, yeteneklerinin, konuşma tarzının görünüşünün ve çevresine uyum biçiminin özelliklerini içeren bir terim olarak ele alınmaktadır. Bütün bu özellikler, bireyde kendine özgü ve ahenkli bir bütün oluşturur. Kişilik adı altında toplanan bu özellikler bireyi diğer bireylerden ayırıcı niteliğe sahip olur (Savran, 1993, Yüksel,2006).

Eysenck ise kişilik yapısını, birbirinden bağımsız iki uçlu yatay ve dikey iki boyut üzerinden değerlendirmiştir. Yatay boyutun bir ucunda içe dönüklük, öteki ucunda dişa dönüklük; dikey boyutun üst ucunda nevrotik, alt ucunda normal tipler bulunmaktadır. Eysenck kişiliğin, dört temel boyutla tanımlanabileceğini ve bu boyutların güvenilir ve geçerli biçimde ölçülebileceğini savunmaktadır. Bireyler psikiyatrik hastalığı olsun veya olmasın, bu boyutların her birinde bir konumda yer alırlar ve kişilik yapısı bu konumların özgül ve biricik bileşimi ile tanımlanabilir. Bütün insanların kişilik yapıları bu iki boyut arasında bir yerde bulunur. Bu yer, gözlem, dereceli ölçek ve testlerle saptanır. Dikey ve yatay boyutlarda yer alan ve kişiliği oluşturan öğeler, birbirinden ayrı olan, ancak, aralarında bağlantı bulunan dört ayrı düzeye yerleştirilmiştir (Goodworth, 1988).

Eysenck'e (1970) göre kişilik, insanın çevreye kendine özgü bir bicimde uyum sağlamasını belirleyen karakterinin, duygusal, bilişsel ve fiziksel yapısının nispeten kararlı ve durağan bir bicimde örgütlenmesidir. Kişilik tipleri insanların davranış örüntülerini tanımlar. Kişilik tiplerinin her birinin güçlü ve zayıf yanları vardır ve hiçbir kişilik tipi bir diğerinden daha iyi değildir (Akt. Pişkin 2004).

Eysenck kişilik teorisi ilk geliştirildiğinde nörotisizm - stabilite ve dışadönüklük- içedönüklük boyutlarını içerirken daha sonra psikotisizm boyutu da eklenmiştir (Lewis ve ark. 2002). Dişa dönüklük, sosyalliği ve dürtüselliği temsil ederken, bu boyutta yüksek puan alan kişiler, insanlarla iletişimi seven, girişken ve yalnız olmaktansa insanlarla olmayı tercih eden biri olarak tanımlanmıştır. Nörotisizm boyutunun duygusal tutarlılığa veya aşırı tepkiselliğe işaret etmekte olduğu ve bu boyutta yüksek puan alan bir 
kişinin kaygıll, depresif, gergin, çekingen, aşırı duygusal ve düşük özgüveni olabileceği öne sürülmüştür. Psikotisizim boyutu ise soğuk, mesafeli, saldırgan, güvensiz, duygusuz, tuhaf ve empati kuramama, suçluluk ve diğer insanlara karşı duyarsızlık gibi daha çok sıra dışı kişilik özelliklerini ifade etmektedir (Eysenck ve Eysenck 1975).

Eysenck'in tanımladığı ayırıcı kişilik özelliklerinin belli duygu ve davranışlarla ilişkili olduğu bulunmuştur. Nörotisizm'in kayg1, korku depresyon, düşük benlik saygısı, duygusal ve mantık dışı davranışlar göstermeye yönelik yatkınlık ile ilişkili olduğu bulunmuştur. Dışa dönüklük ise sosyal olmak, partilere gitmekten, şaka yapmaktan hoşlanmak, birçok arkadaşa sahip olmak, dürtüsellik, kontrolsüz duygular ve bazen güvenilir olmayan kişilik özellikleri göstermekle ilişkilendirilmiştir. Son olarak, psikotisizm saldırganlık, mesafeli davranma, antisosyal davranışlar ve diğer insanlara karşı duyarsız davranma ile ilişkili bulunmuştur (Eysenck ve Eysenck 1975). Eysenck, bu ayırıcı kişilik özelliklerinin birbirinden bağımsız boyutlar olduğunu belirtmiştir (Eysenck ve Eysenck 1964, 1968).

Cattell'e (1969) göre içedönüklük, dış dünyada olanlarla ilişkili olmanın tersine, içsel düşünce ve duyguların zihni meşgul etmesi; Good'a (1959) göre ise, acık etkinliklere karşı gizli ve simgesel etkinliklerin tercih edilmesi, sosyal temastan çekilme eğilimi şeklinde görülen karmaşık bir kişilik özelliğidir. Loevinger'e (1976) göre dışadönükler, dış faktörlerden hareket ederlerken, içedönükler iç ve öznel faktörlerden harekete geçerler (Akt. Henjum, 1983).

Eysenck sözü edilen bu üç boyutun (içedönüklük, nevrotizm, psikotizm) normal kişilik yapısının bir parçası olduğunu öne sürmektedir. Bu üç boyut da iki uçludur. Dişadönüklük için bir uçta dışadönüklük diğer uçta içedönüklük, nevrotizm için bir uçta nevrotizm diğer uçta duygusal kararlılık ve psikotizm için de bir uçta psikotizm diğer uçta ise süperego gücü yer almaktadır (İnanç ve Yerlikaya, 2008).

Kişilik hayatın ilk yıllarında şekillenmeye başlamaktadır. Birbirlerinin duygularını anlayan ve iletişim kurmaya istekli olan bireyler arasında oluşan yakınlaşma kişilerarası ilişkilerde önemli yer tutmaktadır. Yaşamın ilk yıllarında kurulan yakın ilişkiler, ilerleyen yıllarda kurulacak olan ilişkilerin temelini oluşturmaktadır. Bireyin çevresindeki insanlarla kurmuş olduğu yakın ilişkiler bireyin kendisine ilişkin bilgiler bütünü olan kişiliğinin oluşmasında önemlidir. Sosyal ilişkileri içerisinde birey birçok insanla iletişim kurmaktadır, ancak kendisi için önemli olan insanlarla kurduğu yakın ilişkiler kişiliğinin şekillenmesinde daha baskın rol oynamaktadır (Hamarta, 2002). 
Hamarta (2002), çocuğun kişilik gelişiminde ilk yıllarda annesi ile (veya bakımını üstlenen kişi ile) kurmuş olduğu yakın ilişkilerin hayatının her alanında etkili olduğunu belirtmiştir.

Bebeklik ve çocukluktaki yaşantılar, anne-baba tutumları ve uyarıcı zenginliği kişiliğin şekillenmesinde ve sınırların oluşmasında etkili faktörlerdir. Bu yaşantıların farklı olması her bireyin kişiliğinin kendine özgü olmasina neden olmaktadır.

Kişilerarası ilişkiler insan yaşamında büyük rol oynamaktadır. İlişki, bir kişinin diğer bir kişiye ya da kişilere karşı sergilediği davranışların bütünüdür (Leary, 1957). Kişilerarası ilişkilerin insan yaşamındaki önemi yadsınamaz. Günlük yaşamda kurulan ilişkiler bireyi etkilemekte ve bireyin de başkalarını etkilemesi söz konusu olmaktadır. Kurulan bu ilişkilerde, kullanılan kişilerarası ilişki tarzları bireylerin yaşam kalitelerini etkilemekte ve ilişkilerini yapılandırmaktadır. Kişiler arası ilişkilerin yapılandırılmasında bireyin kendini ve ilişkide olduğu diğer insanları hayatının neresinde algıladığı önemli bir belirleyicidir. Aynı zamanda bireyin kendisi ve diğer bireylere ilişkin yüklemeleri kişiler arası ilişkilerinde nasıl davranacağını da belirleyebilmektedir. Dolayısıyla kişiler arası ilişkilerdeki doyum yaşamın diğer alanlarını da kapsayacak şekilde bireylerin iyi oluş düzeylerine etki etmektedir.

Plutchik (1997), kişilerarası ilişkileri genel anlamıyla, bireylerin diğer kişilerle olan ilişkilerinde yaşadıkları duygu, düşünme ve davranış stilleri olarak tanımlamaktadır. Kişilerarası ilişki kavramı tanımlanırken, kişilerarası ilişki ve iletişim birlikte ele alınmakta ve bu kavram kişilerarası ilişki bağlamında tanımlanmaktadır.

Bireyin benlik algısını, kendine verdiği değeri, kendine olan saygısını ve güvenini ölçme konusunda fırsat vermesi açısından kişilerarası ilişkiler bireyin yaşamının çok önemli unsurlarından biri olma özelliğini taşımaktadır.

Alanyazın incelendiğinde kişilerarası ilişki tarzlarının farklı alt boyutlarla tanımlandığı görülmektedir. Kişilerarası ilişki tarzları, Şahin, Batıgün ve Koç (2011), Öztan, (1996) tarafından yapılan çalışmalarda baskın, kaçıngan, öfkeli, duygudan kaçınan, manipulatif ve küçümseyici tarzlar şeklinde ele alındığı gibi, bu araştırmada olduğu gibi Şahin, Durak ve Yasak (1994), Hasta ve Güler (2013) tarafından besleyici (açık ve saygılı) ve ketleyici/zehirleyici (saygısız/benmerkezci ve küçümseyici) şeklinde de ele alınmıştır. Kişilerarası ilişkilerde besleyici ilişki tarzı, kişilerarası ilişkilerde bireylerin yaşantılarını iyileştiren, doyurucu ve besleyici tarzdaki ilişkileri; ketleyici ya da zehirleyici ilişki tarzları ise, yıkıcı etkisi bulunan ve olumsuz yaşantılara neden olabilen ilişki tarzlarını nitelemektedir. Karşılıklı anlayış 
ve empatinin yer aldığı besleyici ilişki tarzları, olumlu kişilerarası ilişkilere hizmet ederken; zorlama ve baskının yer aldığı ketleyici ilişki tarzları, kişilerarası ilişiklerde çatışmalara neden olabilmektedir. Besleyici ilişkiler, gereksinimlerini karşısındakine açıkça ifade etme, karşısındakine kabullenici ve saygılı bir tarzda yaklaşma ve yapıcı konuşma gibi olumlu özelliklerle açıklanmaktadır. Ketleyici/zehirleyici ilişkiler ise, kendini üstün görme, karşısındakini küçümseme, başkalarına sözle sataşma ya da onlarla alay etme ve kolayca öfkelenebilme gibi özelliklerle ifade edilmektedir (Greenwald, 1999; Tutkun, Güner, Ağaoğlu ve Soslu, 2010; Hasta ve Güler, 2013).

Kişilerarası ilişkilerde açık, saygıllı, rasyonel gibi olumlu yani besleyici ilişki tarzları insanların birbirlerini daha iyi anlamalarını ve topluma uyumlarını kolaylaştırırken; küçümseyici, saygısız, saldırgan gibi olumsuz yani zehirleyici ilişki tarzları bunun aksine doğru ve sağlıklı iletişimi güçleştirmektedir (Aydın, 1996).

Sullivan (1953)'a göre, bireyin davranışları yalnızca geçmiş ve şimdiki kişilerarası etkileşimleri içinde değerlendirildiğinde anlaşılabilir. Ona göre kişilik, insan yaşamını karakterize eden yinelenen ve sürekliliği olan kişilerarası durumlardır; görülemeyen ya da objektif yöntemlerle ölçülemeyen konular hakkında tartışmak anlamsızdır.

Kişilerarası tarz ise bireyin belirli bir durum karsısında gösterdiği davranıştan farklı olarak, çeşitli ilişki ve durumlarda genel olarak sergilediği temel davranış eğilimi ve kişilik örüntüsüdür. Bireylerin kişilik tarzlarının, kişilerarası etkileşimlerindeki uyumluluklarını etkilemesi kaçınılmazdır (Kiesler, 1983).

\section{Araştırmanın Amacı ve Önemi}

Bireylerin kişilerarası ilişki tarzları psiko-sosyal gelişim süreçlerinden etkilendiği için bireyin ruhsal-duygusal özelliklerinden bağımsız değildir. Konuyla ilgili olarak literatür incelendiğinde üniversite öğrencilerinin kişilerarası ilişki tarzlarıyla psikolojik eğilimleri arasındaki ilişkinin incelendiği araştırmaya rastlanmamış olmakla beraber çeşitli yaş ve meslek gruplarının kişilik özelliklerinin incelendiği pek çok araştırmaya rastlanmaktadır. Hem kişilerarası ilişki tarzları açısından hem de kişilik özellikleri açısından sağlıklı özelliklere sahip olmayı gerektiren öğretmenlik mesleğini seçen üniversite öğrencilerinin, her iki özellik açısından incelendiği bu araştırma ile literatüre katkı sağlanacaktır.

$\mathrm{Bu}$ araştırmada Gaziantep Üniversitesi Eğitim Fakültesi’nde öğrenim görmekte olan öğrencilerin psikolojik eğilimleriyle kişilerarası ilişki tarzları arasındaki ilişki, bazı değişkenler açısından incelenmiştir. 
Sosyal Bilimler Dergisi 59

Araştırmanın ana problemi doğrultusunda aşağıdaki alt problemler oluşturulmuş ve veriler analiz edilmiştir:

1. Öğrencilerin psikolojik eğilim ve kişilerarası ilişki tarzları puanları; cinsiyet, ailelerinde sıklıkla psikolojik desteğe ihtiyacı olan bireylerin olup olmaması, anne babalarının birlikte-ayrı yaşıyor olması, öğrenim gördükleri bölümler, öğrenim gördükleri sınıf düzeyi, algıladıkları gelir düzeyleri, anne ve babalarının eğitim düzeyi, algıladıkları anne-baba tutumlarına göre anlamlı derecede farklılaşmakta mıdır?

2. Öğrencilerin psikolojik eğilimlerine ait puanlarıyla kişilerarası ilişki tarzları puanları arasında anlamlı bir ilişki var mıdır?

Lisans düzeyinde öğrenim görmekte olan öğrencilerin, eğitim gördükleri bölüm ve içinde bulundukları yaş dönemi açısından değerlendirildiğinde kişilik özelliklerinin öneminin bu dönemlerde bir kat daha arttığı bilinmektedir. İlk yetişkinlik veya gençlik çağlarına denk gelen, hayatıyla ilgili önemli seçimler yapan, yeni değerler kazanan ve farkındalık düzeyi her geçen gün artan bir dönemde kişilik özelliklerinin, kişilerarası ilişki tarzları ve öğrenim gördükleri bölümler açısından incelendiği bir araştırma olması nedeniyle alan yazına katkı sağlanacaktır.

\section{Araştırmanın Yöntem}

$\mathrm{Bu}$ araştırma, betimsel tarama modelinde ilişkisel tarama yöntemi kullanılan betimsel bir araştırmadır.

\section{Evren ve Örneklem}

Araştırmanın evreni 2012-2013 eğitim-öğretim yllında Gaziantep Üniversitesi Eğitim Fakültesi Sınıf Öğretmenliği, İlköğretim Matematik Öğretmenliği, Türkçe Öğretmenliği, Rehberlik ve Psikolojik Danışmanlık bölümlerinde öğrenim görmekte olan öğrencilerden oluşmaktadır.

Araştırmanın örneklemi 2012-2013 eğitim-öğretim yılında Gaziantep Üniversitesi Eğitim Fakültesi Sınıf Öğretmenliği, İlköğretim Matematik Öğretmenliği, Türkçe Öğretmenliği, Rehberlik ve Psikolojik Danışmanlık bölümlerinde öğrenim görmekte olan öğrenciler arasından seçkisiz örnekleme yoluyla seçilen 572 öğrenciden oluşmaktadır.

\section{Veri toplama araçları}

$\mathrm{Bu}$ araştırmada, araştırmacı tarafından hazırlanan demografik değişkenleri içeren "Kişisel Bilgi Formu", adayların psikolojik belirtilerini ölçek için "Eysenck Kişilik Envanteri (Kısa form)" ve bağlanma stillerini belirlemek amacıyla "Kişilerarası İlişki Tarzları Ölçeği" kullanılmıştır. 
Eysenck Kişilik Envanteri:

Eysenck Kişilik Envanteri günümüzde tüm dünyada içedönüklük ve dışadönüklük kişilik yapısının ölçülmesinde en yaygın kullanılan ölçme araçlarından biri olarak kabul edilmektedir. Envanter temelde patolojik semptomları değil, daha çok normal davranışları saptamak için geliştirilmiştir (Pişkin, 2004).

Türkçe'ye Karanc1, Dirik ve Yorulmaz (2007) tarafından uyarlanmıştır. Anket, 24 madde olup, kişiliği üç ana faktörde değerlendirmektedir: dişadönüklük, nörötisizm, psikotisizm. Ayrıca yalan söyleme alt boyutu ile anketin uygulanması esnasındaki yanlılı̆̆ engellemek ve geçerliliği ile ilgili kontrol amaçlanmaktadır. Her bir faktörün 6 madde ile değerlendirildiği bu ankette katılımcıdan 24 soruya Evet (1)Hayır (0) formatıyla cevap vermeleri istenir. Her bir kişilik özelliği için alınabilecek puan 0 ile 6 arasında değişmektedir. Dışa dönüklük, nörotisizm, psikotisizm ve yalan boyutları için yapılan iç güvenirlik analizinde KuderRichardson korelasyon katsayıları sirasiyla .78, .65, .42, ve .64 olarak bulunmuştur. Ölçeklerin test-tekrar test güvenilirlikleri ise sırasıyla $.84, .82$, .69 ve .69 olarak bulunmuştur. Ayrıca, ölçeğin yeterli düzeyde yapı geçerliğine sahip olduğu bulgular arasındadır (Bektaş, Yazıcı ve Altun, 2013)

H.J.Eysenck ve S.B.G. Eysenck, bütün kişilik özelliklerinin üç boyutta incelenebileceğini ileri sürmüştür; $\mathrm{P}($ Psikotizm), N(Nörotizm) ve $\mathrm{E}$ (Dışadönüklük). Bu kişilik boyutlarını ölçmek amacıyla uzun yıllar süren çalışmaları sırasında bir dizi kişilik envanteri geliştirmişlerdir. İlk olarak Maudsley Tıbbi Envanteri geliştirilmiştir. Bu envanter 40 maddeden oluşup nörotizmi ölçmeyi amaçlamaktadır. Bundan sonra geliştirilen Maudsley Kişilik Envanteri (MPI), nörotizmin yanı sıra içedönüklük-dışadönüklüğün ölçülmesi için geliştirilmiştir. Daha sonra Eysenck ve Eysenck (1964), Maudsley Kişilik Envanteri'ne yalan ölçeğini (L) ilave edip geliştirmiş ve Eysenck Personality Inventory (EPI) oluşturulmuştur.

$\mathrm{Bu}$ envanterin asıl formu dört ayrı ölçeğe ait (psikotizm, dışa dönüklük, nörotizın ve yalan) 90 asıl ve 11 yedek olmak üzere 101 maddeden oluşmaktadır. Bu maddelerin 29 tanesi nörotizın, 24 tanesi dışadönüklük, 27 tanesi psikotizm ve 21 tanesi de yalan ölçeğidir. Her madde için 'evet' ve 'hayır' seçenekleri vardır. 'hayır' yanıtı verilmesi gereken sorular dişındaki sorulara 'evet' yanıtı verilmişse 1 puan, hayır yanıtı verilmesi gereken sorulara hayır yanıtı verilmişse 1 puan alınır. Dışa dönüklük bölümünde 13, psikotizm bölümünde 6, nörotizm bölümünde 11 ve yalan bölümünde 14 toplam puanın üzerine çıkıldığında ölçülen değişkene ilişkin belirtinin arttı̆̆ söylenebilir (Öner, 1997).

$\mathrm{Bu}$ araştırmada kullanılan Eysenck Kişilik Envanteri (kısa form) 
Sosyal Bilimler Dergisi 61

Türkce'ye Topçu (1982) tarafından çevirip uyarlama çalışmaları yapılmıştır. Topçu (1982) 566 erkek ve 526 kadın toplam 1092 kişilik Türk örneklem grubuna testi uygulayarak testin tüm ölçeklerinin Türkçe formlarının kabul edilir düzeyde güvenilir olduğunu bulmuştur. Elde edilen tüm güvenirlik katsayıları $\mathrm{p}<0,01$ düzeyinde anlamlı bulunmuştur. Testin tüm ölçeklerinin ilgili kişilik boyutlarını ölçmek için güvenle kullanılabileceği ifade edilmiştir (Akt. Tokgöz, 1997).

$\mathrm{Bu}$ araştırmada kullanılan EPQ; EPI'ya psikotizm ölçeğinin katılmasıyla oluşturulan en son ve en yeni halidir. Birçok Avrupa ülkesinde suçlu olan ve suçlu olmayan gruplara uygulanmış olan Eysenck Kişilik Envanteri yolu ile başarılı sonuçlar elde edilmiştir. Testin basit bir dille formüle edilmiş olması testin kullanım değerini artırmaktadır.

Kişilerarası İlişki Tarzları Ölçeği:

Bu ölçek, Şahin, Durak ve Yasak (1994) tarafından geliştirilmiştir. Ölçek, bireylerin diğer bireylerle olan etkileşim tarzını belirlemeyi amaçlamaktadır. 31 maddeden oluşan ölçekte, her madde 0-3 arasında değişen Likert tipi bir ölçek üzerinde değerlendirilmektedir. Ölçek, besleyici ve ketleyici ilişki tarzlarını ölçen iki alt ölçekten meydana gelmektedir. Her bir alt ölçek, kendi içinde iki alt boyuta ayrılmaktadır. Besleyici ilişki tarzları alt boyutu açık ve saygılı ilişki; ketleyici ilişki tarzları alt boyutu ise benmerkezci ve küçümseyici ilişki alt boyutlarından oluşmaktadır. Ölçeğin tamamı için hesaplanan Cronbach Alpha iç tutarlılık katsayısı.79'dur. Alt ölçeklerin iç tutarlılığı ise; açık ilişki tarzı için .73, saygılı ilişki tarzı için .70, benmerkezci ilişki tarzı için .56 ve küçümseyici ilişki tarzı için .78 olarak belirlenmiştir (Şahin, Durak ve Yasak, 1994).

Ayrıca Şahin, Durak ve Yasak (1994) tarafından ölçeğin yapı geçerliğini belirlemek amaciyla uygulanan faktör analizi sonucunda, ilk faktörü oluşturan zehirleyici ilişki tarzı alt boyutu maddeleri toplam varyansın \%15.7'sini açıklamıştır. İkinci faktörü oluşturan besleyici ilişki tarzı alt boyutu maddeleri ise toplam varyansın \%13.1' ini açıklamıştır. Bu iki alt boyutun Cronbach Alfa değerleri hesaplanmış, bu değerler Zehirleyici İlişki Tarzları alt boyutu için .81, Besleyici İlişki Tarzları alt boyutu için .80 olarak bulunmuştur. Sonuç olarak KIÖ'nin yapı geçerliğinin yeterli düzeyde olduğu ortaya konulmuştur.

Ölçekteki 1, 3, 5, 7, 9, 11, 13, 15, 17, 19, 21, 23, 25, 27, 29, 31. Maddelerden elde edilen puanlar besleyici ilişki tarzları ve 2, 4, 6, 8, 10, 12, $14,16,18,20,22,24,26,28,30$. Maddelerinden elde edilen puanlar da zehirleyici ilişki tarzları puanlarını vermektedir. Her ikisinin birleşiminden elde edilen toplam puandır. Besleyici ilişki tarzında yüksek puanlar kişilerarası ilişkilerde olumlu bir tarzın göstergesi, zehirleyici ilişki tarzında 
yüksek puanlar ise kişilerarası ilişkilerde olumsuz bir tarzın göstergesi olarak değerlendirilmektedir. Ölçeğin iç tutarlılık güvenirliğini sınamak için hesaplanan Cronbach Alfa güvenirlik katsayısı .79 olarak bulunmuştur. Ayrıca tek ve çift maddelerden elde edilen iki yarım test güvenirliği $r=.63$ ( $p<.001$ ) olarak hesaplanmıştır. Madde toplam puan korelasyonlarına bakılmış ve ölçeğin toplam puanla maddeler arasındaki korelasyonu .10 ile .48 arasında tespit edilmiştir (Savaşır ve Şahin, 1997).

\section{Verilerin Analizi ve Kullanılan İstatistiksel Teknikler}

Araştırmacı tarafından toplanan veriler, SPSS 17.00 paket programına girilerek analizleri gerçekleştirilmiştir. Veriler girildikten sonra betimsel analizler yapılara dağılım hakkında genel bilgilere ulaşılmıştır. Dağılımın normalliğinin test edilmesi amaciyla Kolomogrov Smirnof testinden yararlanılmış, test sonuçlarının ( $p>.05)$ normal dağılım özelliğinde odluğu belirlendikten sonra, gruplara ait ortalamalar arasındaki farkın anlamlığını test etmek için $t$ testi ve ANOVA testleri yapılmış sonuçlar Bulgular kısmında tablolar halinde sunulmuştur.

\section{Bulgular}

$\mathrm{Bu}$ bölümde veri toplama araçları kullanılarak elde edilen veriler üzerinde yapılan istatistiksel analizlere ait bulgulara yer verilmiştir. Veri toplama araçlarından Eysenck Kişilik Envanterinin alt ölçekleri olan "dışadönüklük", "nevrotizm" ve psikotizm alt ölçekleri ve Kişilerarası İlişki Tarzları Ölçeğinin alt ölçekleri olan "Besleyici ilişki tarzı" ve "Zehirleyici ilişki tarzı" puanlarının cinsiyet, ailelerinde sıklıkla psikolojik desteğe ihtiyacı olan bireylerin olup olmaması, anne ve babanın birlikte-ayrı yaşıyor olması, öğrenim gördükleri bölüm, sınıf düzeyi, algıladıkları gelir düzeyi, anne ve babalarının eğitim düzeyi, algıladıkları anne-baba tutumu gibi değişkenler açısından farklılaşma gösterip göstermediği incelenmiştir.

1. Ölçeklerden elde edilen puan ortalamaları arasında öğrencilerin cinsiyetlerine göre anlamlı düzeyde farklılaşma olup olmadığına cevap bulmak için $t$ testi analizinden yararlanılmış ve elde edilen bulgular Tablo 1 'de sunulmuştur. 
Tablo 1. Öğrencilerin Cinsiyetlerine Göre Ölçeklerden Elde Edilen Puanlara Ait Aritmetik Ortalama ve t Testi Değerleri

\begin{tabular}{|c|c|c|c|c|}
\hline Alt Ölcekler & $\begin{array}{c}\mathrm{K} \\
(\mathrm{n}=387) \\
\bar{X}\end{array}$ & $\begin{array}{c}E \\
(\mathrm{n}=185) \\
\overline{\bar{X}}\end{array}$ & $\mathrm{t}$ & p. \\
\hline Dişadönüklük & 3,69 & 3,56 & ,749 &, $006^{*}$ \\
\hline Nevrotik & 3,35 & 3,26 &, 531 & ,312 \\
\hline Psikotik & 1,42 & 1,60 & $-1,687$ & ,487 \\
\hline Besleyici & 46,35 & 45,46 & 1,681 & ,831 \\
\hline Zehirleyici & 25,73 & 28,79 & $-5,979$ &, $000^{*}$ \\
\hline
\end{tabular}

Tablo 1 incelendiğinde; öğrencilerin cinsiyetlerine göre Eysenck Kişilik Envanterinin alt boyutlarından "dışadönüklük" alt boyutundan elde edilen ortalamaların kızlarda; Kişiler Arası İlişki Tarzları ölçeğinin alt boyutlarından "zehirleyici ilişki" tarzları alt boyutundan elde edilen ortalamalarının da erkekler de yüksek olduğu ve bu farkın istatistiksel olarak anlamlı düzeyde olduğu görülmektedir.

2. Ölçeklerden elde edilen puan ortalamaları arasında öğrencilerin ailelerinde sıklıkla psikolojik desteğe ihtiyacı olan bireylerin olup olmamasına göre anlamlı düzeyde farklılaşma olup olmadığına cevap bulmak için $t$ testi analizinden yararlanılmış ve elde edilen bulgular Tablo 2.'de sunulmuştur.

Tablo 2. Öğrencilerin Ailelerinde Sıklıkla Psikolojik Desteğe İhtiyacı Olan Bireylerin Olup Olmamasına Göre Ölçeklerden Elde Edilen Puanlara Ait Aritmetik Ortalama ve t Testi Değerleri

\begin{tabular}{|c|c|c|c|c|}
\hline Alt Ölçekler & $\begin{array}{c}\text { Psikolojik } \\
\text { destek alan } \\
(\mathrm{n}=73) \\
\bar{X}\end{array}$ & $\begin{array}{c}\text { Psikolojik destek } \\
\text { almayan } \\
(\mathrm{n}=498) \\
\bar{X}\end{array}$ & $t$ & p. \\
\hline Dişadönüklük & 3,39 & 3,68 & $-1,194$ & 050 \\
\hline Nevrotik & 4,09 & 3,20 & 3,929 & 077 \\
\hline Psikotik & 1,50 & 1,47 & ,203 & ,966 \\
\hline Besleyici & 46,56 & 46,00 & 761 & ,285 \\
\hline Zehirleyici & 27,34 & 26,62 & ,967 & ,597 \\
\hline
\end{tabular}

Tablo 2 incelendiğinde; öğrencilerin ailelerinde psikolojik destek alan birey olup olmamasına göre Eysenck Kişilik Envanteri ve Kişiler Arası 
İlişki Tarzları ölçeğinin alt boyutlarından elde edilen ortalamalar arasında anlamlı bir farklılaşma olmadığı görülmektedir.

3. Ölçeklerden elde edilen puan ortalamaları arasında öğrencilerin anne-babalarının birlikte veya ayrı yaşıyor olmalarına göre anlamlı düzeyde farklılaşma olup olmadığına cevap bulmak için $t$ testi analizinden yararlanılmış ve elde edilen bulgular Tablo 3.'de sunulmuştur.

Tablo 3. Öğrencilerin Anne Babalarının Birlikte-Ayrı Yaşıyor Olmasına Göre Ölçeklerden Elde Edilen Puanlara Ait Aritmetik Ortalama ve $t$ Testi Değerleri

\begin{tabular}{lcccc}
\hline & $\begin{array}{c}\text { Birlikte } \\
(\mathrm{n}=535)\end{array}$ & $\begin{array}{c}\text { Ayr1 } \\
(\mathrm{n}=37)\end{array}$ & & \\
Alt Ölçekler & $\bar{X}$ & $\bar{X}$ & $\mathrm{t}$ & $\mathrm{p}$. \\
\hline D1şadönüklük & 3,65 & 3,64 &, 005 &, 182 \\
Nevrotik & 3,31 & 3,51 &,- 656 &, 369 \\
Psikotik & 1,47 & 1,59 &,- 611 &, 179 \\
\hline Besleyici & 46,06 & 46,08 &,- 016 &, 934 \\
Zehirleyici & 26,68 & 27,29 &,- 612 &, 452 \\
\hline
\end{tabular}

Tablo 3 incelendiğinde; öğrencilerin anne-babalarının birlikte ye da ayrı yaşıyor olmalarına göre Eysenck Kişilik Envanterinin alt boyutlarından ve Kişiler Arası İlişki Tarzları ölçeğinin alt boyutlarından elde edilen ortalamalar arasında anlamlı bir farklılaşma olmadığı görülmektedir.

4. Ölçeklerden elde edilen puan ortalamaları arasında öğrencilerin öğrenim gördükleri bölümlere göre anlamlı düzeyde farklılaşma olup olmadığına cevap bulmak için $\mathrm{t}$ testi analizinden yararlanılmış ve elde edilen bulgular Tablo 4.'de sunulmuştur.

Tablo 4. Öğrencilerin Öğrenim Gördükleri Bölümlere Göre Ölçeklerden Elde Edilen Puanlara Ait Aritmetik Ortalama ve ANOVA Puanları

\begin{tabular}{|c|c|c|c|c|c|c|c|}
\hline Alt Ölçekler & $\begin{array}{c}\operatorname{PDR}(\mathrm{A}) \\
(\mathrm{n}=145) \\
\frac{X}{X}\end{array}$ & $\begin{array}{c}\text { Sinıf } \\
\text { Öğr.(B) } \\
(\mathrm{n}=144) \\
\bar{X}\end{array}$ & $\begin{array}{c}\text { Türkçe } \\
\text { Öğgr.(C) } \\
(\mathrm{n}=137) \\
\bar{X}\end{array}$ & $\begin{array}{c}\text { Matemati } \\
\text { k Öğr.(D) } \\
(\mathrm{n}=146) \\
\bar{X}\end{array}$ & $\mathrm{~F}$ & p. & $\begin{array}{l}\text { Anl. } \\
\text { Fark }\end{array}$ \\
\hline Dişadönüklük & 3,46 & 3,64 & 3,81 & 3,67 & ,76 &, 51 & \\
\hline Nevrotik & 3,13 & 3,21 & 3,79 & 3,17 & 4,14 &, $00^{*}$ & $\mathrm{C}>\mathrm{A}$ \\
\hline Psikotik & 1,53 & 1,47 & 1,43 & 1,47 &, 18 & ,90 & \\
\hline Besleyici & 46,18 & 45,56 & 46,50 & 46,03 & 62 & ,59 & \\
\hline Zehirleyici & 27,75 & 25,53 & 26,39 & 27,17 & 3,90 &, $00^{*}$ & $\mathrm{~A}>\mathrm{B}$ \\
\hline
\end{tabular}


Sosyal Bilimler Dergisi 65

Tablo 4 incelendiğinde; öğrencilerin öğrenim gördükleri bölümlere göre Eysenck Kişilik Envanterinin alt boyutlarından "nevrotizm" ve Kişiler Arası İlişki Tarzları Ölçeğinin alt boyutlarından "zehirleyici ilişki tarzı" alt boyutundan elde edilen ortalamalar arasında anlamlı bir farklılaşma olduğu görülmüsşür. Bu farklılaşmanın kaynağını belirlemek amacıyla Post-Hoc testlerinden Sheffe testi yapılmış ve "nevrotizm" alt boyutunun ortalamaları arasındaki anlamlı farkın Türkçe öğretmenliği bölümü ile PDR bölümü öğrencileri arasında,Türkçe öğretmenliği bölümü öğrencileri yönünde olduğu; "zehirleyici ilişki tarzı" alt boyutunun ortalamaları arasındaki anlamlı farkın da PDR bölümü ile Sınıf öğretmenliği bölümü öğrencileri arasında, PDR öğrencileri yönünde olduğu görülmektedir.

5. Ölçeklerden elde edilen puan ortalamaları arasında öğrencilerin öğrenim gördükleri sınıf düzeyine göre anlamlı düzeyde farklılaşma olup olmadığına cevap bulmak için ANOVA analizinden yararlanılmış ve elde edilen bulgular Tablo 5'de sunulmuştur.

Tablo 5. Öğrencilerin Öğrenim Gördükleri Sınıf Düzeyine Göre Ölçeklerden Elde Edilen Puanlara Ait Aritmetik Ortalama ve ANOVA Puanları

\begin{tabular}{|c|c|c|c|c|c|c|c|}
\hline Alt Ölcekler & $\begin{array}{c}\text { 1.sinif } \\
(\mathrm{A}) \\
(\mathrm{n}=142) \\
\bar{X}\end{array}$ & $\begin{array}{c}\text { 2.sinif } \\
(\mathrm{B}) \\
(\mathrm{n}=151) \\
\bar{X}\end{array}$ & $\begin{array}{c}\text { 3.sinif } \\
(\mathrm{C}) \\
(\mathrm{n}=159) \\
\bar{X}\end{array}$ & $\begin{array}{c}\text { 4.sinif } \\
(\mathrm{D}) \\
(\mathrm{n}=120) \\
\bar{X}\end{array}$ & $\mathrm{~F}$ & p. & $\begin{array}{l}\text { Anl. } \\
\text { Fark }\end{array}$ \\
\hline Dişadönüklük & 3,52 & 3,49 & 3,82 & 3,76 & 1,09 & 35 & \\
\hline Nevrotik & 3,36 & 3,34 & 3,35 & 3,20 & ,20 & 89 & \\
\hline Psikotik & 1,24 & 1,45 & 1,62 & 1,62 & 3,56 &, $01^{*}$ & $\mathrm{C}, \mathrm{D}>\mathrm{A}$ \\
\hline Besleyici & 46,64 & 46,02 & 45,54 & 46,13 & 87 & 45 & \\
\hline Zehirleyici & 25,91 & 26,05 & 27,35 & 27,67 & 3,22 &, $02^{*}$ & $\mathrm{D}>\mathrm{A}$ \\
\hline
\end{tabular}

Tablo 5 incelendiğinde; öğrencilerin öğrenim gördükleri sınıf düzeylerine göre Eysenck Kişilik Envanterinin alt boyutlarından "psikotizm" ve Kişiler Arası İlişki Tarzları Ölçeğinin alt boyutlarından "zehirleyici ilişki tarzı" alt boyutundan elde edilen ortalamalar arasında anlamlı bir farklılaşma olduğu görülmektedir. Bu farklılaşmanın kaynağını belirlemek amaciyla Post-Hoc testlerinden Sheffe testi yapılmış ve "psikotizm" alt boyutunun ortalamaları arasındaki anlamlı farkın 3. ve 4. sınıflar ile 1.sınıf öğrencileri arasında, 3.ve4.sınıf öğrencileri yönünde; "zehirleyici ilişki tarzı" alt boyutunun ortalamaları arasındaki anlamlı farkın da 4.sınıf ile 1.sınıf öğrencileri arasında, 4.sınıf öğrencileri yönünde olduğu görülmektedir. 
6. Ölçeklerden elde edilen puan ortalamaları arasında öğrencilerin algıladıkları gelir düzeylerine göre anlamlı düzeyde farklılaşma olup olmadığına cevap bulmak için ANOVA analizinden yararlanılmış ve elde edilen bulgular Tablo 6.'da sunulmuştur.

Tablo 6. Öğrencilerin Algıladıkları Gelir Düzeylerine Göre Ölçeklerden Elde Edilen Puanlara Ait Aritmetik Ortalama ve ANOVA Puanları

\begin{tabular}{lcccccc}
\hline & $\begin{array}{c}\text { Düşük } \\
(\mathrm{A}) \\
(\mathrm{n}=55)\end{array}$ & $\begin{array}{c}\text { Orta } \\
(\mathrm{B}) \\
(\mathrm{n}=500)\end{array}$ & $\begin{array}{c}\text { Yüksek } \\
(\mathrm{C}) \\
(\mathrm{n}=17)\end{array}$ & & & \\
\multicolumn{1}{c}{ Alt Ölçekler } & $\bar{X}$ & $\bar{X}$ & $\bar{X}$ & $\mathrm{~F}$ & $\mathrm{p}$. & $\begin{array}{c}\text { Anlamlı } \\
\text { Fark }\end{array}$ \\
\hline Dişadönüklük & 3,34 & 3,64 & 4,88 & 4,12 &, $01^{*}$ & $\mathrm{C}>\mathrm{A}-\mathrm{B}$ \\
Nevrotik & 3,87 & 3,27 & 3,05 & 2,89 &, 05 & \\
Psikotik & 1,65 & 1,44 & 2,11 & 3,60 &, $02^{*}$ & $\mathrm{C}>\mathrm{A}-\mathrm{B}$ \\
\hline Besleyici & 47,34 & 45,88 & 47,29 & 1,91 &, 14 & \\
Zehirleyici & 26,61 & 26,6 & 30,41 & 3,45 &, $03^{*}$ & $\mathrm{C}>\mathrm{A}-\mathrm{B}$ \\
\hline
\end{tabular}

${ }^{*} \mathrm{p}<.05$

Tablo 6 incelendiğinde öğrencilerin algıladıkları gelir düzeyine göre Eysenck Kişilik Envanterinin alt boyutlarından "dışadönüklük", "psikotizm" ve Kişiler Arası İlişki Tarzları Ölçeğinin alt boyutlarından "zehirleyici ilişki tarzı" alt boyutlarından elde edilen ortalamalar arasında anlamlı bir farklılaşma olduğu görülmektedir. Bu farklılaşmanın kaynağını belirlemek amaciyla Post-Hoc testlerinden Sheffe testi yapılmış ve Eysenck Kişilik Envanterinin alt boyutlarından "dışadönüklük" ve "psikotizm"; Kişiler Arası İlişki Tarzları Ölçeğinin alt boyutlarından "zehirleyici ilişki tarzı" alt boyutundan elde edilen ortalamalar arasındaki anlamlı farkın yüksek gelir düzeyi algılayanlarla düşük ve orta gelir düzeyi algılayanlar arasında, yüksek gelir düzeyi algılayanlar yönünde olduğu görülmüştür.

7. Ölçeklerden elde edilen puan ortalamaları arasında öğrencilerin annelerinin eğitim düzeyine göre anlamlı düzeyde farklılaşma olup olmadığına cevap bulmak için ANOVA analizinden yararlanılmış ve elde edilen bulgular Tablo 7'de sunulmuştur. 
Tablo 7. Öğrencilerin Annelerinin Eğitim Düzeyine Göre Ölçeklerden Elde Edilen Puanlara Ait Aritmetik Ortalama ve ANOVA Puanları

\begin{tabular}{|c|c|c|c|c|c|c|c|}
\hline Alt Ölçekler & $\begin{array}{c}\text { Okur- } \\
\text { yazar } \\
\text { değil } \\
(\mathrm{A}) \\
(\mathrm{n}=152) \\
\bar{X}\end{array}$ & $\begin{array}{c}\text { İlkokul } \\
\text { mez.(B) } \\
(\mathrm{n}=328) \\
\bar{X}\end{array}$ & $\begin{array}{c}\text { Lise } \\
\text { Mez. } \\
(\mathrm{C}) \\
(\mathrm{n}=64) \\
\bar{X}\end{array}$ & $\begin{array}{c}\text { Üniv } \\
\text { mez. } \\
(\mathrm{D}) \\
(\mathrm{n}=28) \\
\bar{X}\end{array}$ & $\mathrm{~F}$ & p. & $\begin{array}{l}\text { Anl. } \\
\text { Fark }\end{array}$ \\
\hline Dışadönüklük & 3,61 & 3,58 & 3,96 & 3,89 & 85 & 46 & \\
\hline Nevrotik & 3,44 & 3,28 & 3,18 & 3,42 & 40 & ,75 & \\
\hline Psikotik & 1,46 & 1,37 & 1,84 & 2,03 & 5,43 &, $00^{*}$ & $\mathrm{D}>\mathrm{B}$ \\
\hline Besleyici & 46,28 & 46,11 & 45,42 & 45,71 & 37 & ,77 & \\
\hline Zehirleyici & 26,506 & 26,50 & 27,87 & 27,78 & 1,33 & ,26 & \\
\hline
\end{tabular}

Tablo 7. incelendiğinde; öğrencilerin annelerinin eğitim düzeylerine göre Eysenck Kişilik Envanterinin alt boyutlarından "psikotizm" alt boyutundan elde edilen ortalamalar arasında anlamlı bir farklılaşma olduğu görülmüştür. Bu farklılaşmanın kaynağını belirlemek amacıyla Post-Hoc testlerinden Sheffe testi yapılmış bu farkın annesi üniversite mezunu olanlarla annesi ilkokul mezunu olanlar arasında olduğu görülmektedir.

8. Ölçeklerden elde edilen puan ortalamaları arasında öğrencilerin babalarının eğitim düzeyine göre anlamlı düzeyde farklılaşma olup olmadığına cevap bulmak için ANOVA analizinden yararlanılmış ve elde edilen bulgular Tablo 8'de sunulmuştur.

Tablo 8. Öğrencilerin Babalarının Eğitim Düzeyine Göre Ölçeklerden Elde Edilen Puanlara Ait Aritmetik Ortalama ve ANOVA Puanları

$\begin{array}{llll}\text { Okur- } & & & \\ \text { yazar } & \text { İlk. } & \text { Lise } & \text { Üniv. } \\ \text { değil } & \text { Mez } & \text { mez. } & \text { mez. }\end{array}$

$\begin{array}{llll}(\mathrm{A}) & \text { (B) } & \text { (C) } & \text { (D) }\end{array}$

$(\mathrm{N}=24) \quad(\mathrm{n}=307) \quad(\mathrm{n}=125) \quad(\mathrm{n}=116) \quad$ Anl.

\begin{tabular}{lccccccc}
\multicolumn{1}{c}{ Alt Ölçekler } & $\bar{X}$ & $\bar{X}$ & $\bar{X}$ & $\bar{X}$ & $\mathrm{~F}$ & $\mathrm{p}$. & Fark \\
\hline Dışadönüklük & 3,37 & 3,52 & 3,90 & 3,76 & 1,43 &, 23 & \\
Nevrotik & 3,58 & 3,41 & 3,12 & 3,25 &, 93 &, 42 & \\
Psikotik & 1,16 & 1,40 & 1,54 & 1,69 & 2,64 &, $04^{*}$ & D $>$ A \\
\hline Besleyici & 44,79 & 45,97 & 45,86 & 46,78 & 1,02 &, 38 & \\
Zehirleyici & 28,95 & 26,22 & 26,86 & 27,43 & 2,48 &, 06 & \\
\hline \multicolumn{1}{c}{${ }^{*} \mathrm{p}<.05$} & & & & & & &
\end{tabular}


Tablo 8 incelendiğinde; öğrencilerin babalarının eğitim düzeylerine göre Eysenck Kişilik Envanterinin alt boyutlarından "psikotizm" alt boyutundan elde edilen ortalamalar arasında anlamlı bir farklılaşma olduğu görülmektedir. Bu farklılaşmanın kaynağını belirlemek amacıyla Post-Hoc testlerinden Sheffe testi yapılmış ve "psikotizm" alt boyutunun ortalamaları arasındaki bu farkın babası üniversite mezunu olan öğrencilerle babası okur-yazar olmayan öğrenciler arasında, babası üniversite mezunu olan öğrenciler yönünde olduğu görülmüştür.

9. Ölçeklerden elde edilen puan ortalamaları arasında öğrencilerin algıladıkları anne tutumlarına göre anlamlı düzeyde farklılaşma olup olmadığına cevap bulmak için ANOVA analizinden yararlanılmış ve elde edilen bulgular Tablo 9'da sunulmuştur.

Tablo 9. Öğrencilerin Algıladıkları Anne Tutumlarına Göre Ölçeklerinden Elde Edilen Puanlara Ait Aritmetik Ortalama ve ANOVA Puanları

\begin{tabular}{|c|c|c|c|c|c|c|}
\hline & $\begin{array}{c}\text { Demokratik } \\
\text { (A) } \\
(\mathrm{n}=432) \\
-\end{array}$ & $\begin{array}{c}\text { Gevşek } \\
(\mathrm{B}) \\
(\mathrm{n}=90) \\
-\end{array}$ & $\begin{array}{c}\text { Aşırı } \\
\text { disiplinli } \\
(\mathrm{C}) \\
(\mathrm{n}=50)\end{array}$ & & & Anlamlı \\
\hline Alt Ölçekler & $\bar{X}$ & $\bar{X}$ & $\bar{X}$ & $\mathrm{~F}$ & p. & Fark \\
\hline Dişadönüklük & 3,78 & 3,27 & 3,14 & 4,485 &, $012^{*}$ & $\mathrm{~A}>\mathrm{C}$ \\
\hline Nevrotik & 3,20 & 3,66 & 3,72 & 3,710 &, $025^{*}$ & $\mathrm{C}>\mathrm{A}$ \\
\hline Psikotik & 1,45 & 1,67 & 1,42 & 1,570 & ,209 & \\
\hline Besleyici & 46,28 & 44,95 & 46,20 & 1,917 & 148 & \\
\hline Zehirleyici & 26,61 & 28,26 & 24,90 & 5,627 &, $004^{*}$ & $B>C$ \\
\hline
\end{tabular}

$$
{ }^{*} \mathrm{p}<.05
$$

Tablo 9. incelendiğinde öğrencilerin algıladıkları anne tutumlarına göre Eysenck Kişilik Envanterinin alt boyutlarından "dışadönüklük", "nevrotizm" ve Kişiler Arası İlişki Tarzları Ölçeğinin alt boyutlarından "zehirleyici ilişki tarzı" alt boyutundan elde edilen ortalamalar arasında anlamlı bir farklılaşma olduğu görülmektedir. Bu farklılaşmanın kaynağını belirlemek amaciyla Post-Hoc testlerinden Sheffe testi yapılmış ve "dışadönüklük" alt boyutunun ortalamaları arasındaki farkın annesinin tutumunu demokratik algılayan öğrencilerle aşırı disiplinli algılayanlar arasında, annesin tutumunu demokratik algilayanlar yönünde yüksek olduğu; "nevrotizm" alt boyutunun ortalamaları arasındaki farkın annesinin tutumunu aşırı disiplinli algılayan öğrencilerle demokratik algılayan öğrenciler arasında, annesini disiplin algılayanlar yönünde yüksek olduğu; "zehirleyici ilişki tarzı" alt boyutunun ortalamaları arasındaki anlamlı farkın 
da annesinin tutumunu gevşek algılayan öğrencilerle aşırı disiplinli algılayan öğrenciler arasında, annesinin tutumunu gevşek algılayan öğrenciler yönünde yüksek olduğu görülmüştür.

10. Ölçeklerden elde edilen puan ortalamaları arasında öğrencilerin algıladıkları baba tutumlarına göre anlamlı düzeyde farklılaşma olup olmadığına cevap bulmak için ANOVA analizinden yararlanılmış ve elde edilen bulgular Tablo 10'da sunulmuştur.

Tablo 10. Öğrencilerin Algıladıkları Baba Tutumlarına Göre Ölçeklerden Elde Edilen Puanlara Ait Aritmetik Ortalama ve ANOVA Puanları

Elde Edilen Pşırı

Demokratik Gevşek disiplinli

(A) $\quad$ (B) $\quad$ (C)

\begin{tabular}{lcccccc} 
Alt Ölçekler & $(\mathrm{n}=405)$ & $(\mathrm{n}=86)$ & $(\mathrm{n}=81)$ & & & Anlamlı \\
& $\bar{X}$ & $\bar{X}$ & $\bar{X}$ & $\mathrm{~F}$ & $\mathrm{p}$. & Fark \\
\hline Dişadönüklük & 3,78 & 3,45 & 3,17 & 3,923 &, $020^{*}$ & $\mathrm{~A}>\mathrm{C}$ \\
Nevrotik & 3,22 & 3,54 & 3,55 & 1,843 &, 159 & \\
Psikotik & 1,49 & 1,51 & 1,39 &, 297 &, 743 & \\
\hline Besleyici & 46,19 & 44,90 & 46,67 & 2,210 &, 111 & \\
Zehirleyici & 26,70 & 26,67 & 26,87 &, 033 &, 968 & \\
\hline
\end{tabular}

${ }^{*} \mathrm{p}<.05$

Tablo 10 incelendiğinde öğrencilerin algıladıkları baba tutumlarına göre Eysenck Kişilik Envanterinin alt boyutlarından "dışadönüklük" alt boyutundan elde edilen ortalamalar arasında anlamlı bir farklılaşma olduğu görülmektedir. Bu farklılaşmanın kaynağını belirlemek amacıyla Post-Hoc testlerinden Sheffe testi yapılmış bu farkın babasının tutumunu demokratik algılayan öğrencilerle babasının tutumunu aşırı disiplinli algılayanlar arasında,babasının tutumunu demokratik algilayanlar yönünde yüksek olduğu görülmüş̧tür.

11. Araştırmada kullanılan ölçekler ve ölçeklere ait ailt boyutlardan elde edilen puanlar arasındaki ilişki Pearson korelasyon katsayısı hesaplanarak Tablo 11'de sunulmuştur. 
Tablo 11. Öğrencilerin Ölçeklerden Aldıkları Puanlara Ait Korelasyon Değerleri

\begin{tabular}{|c|c|c|c|c|}
\hline & Nevrotik & Psikotik & Besleyici & Zehirleyici \\
\hline Dışadönüklük & $-265^{* *}$ &, $116^{* *}$ & $196^{* *}$ &, $086^{*}$ \\
\hline Nevrotik & & -,017 - - - &,$- 163^{* *}$ & $149^{* *}$ \\
\hline Psikotik & & &,- 054 &, $353^{* *}$ \\
\hline Besleyici & & & &,$- 203^{* *}$ \\
\hline
\end{tabular}

Tablo 11 incelendiğinde; öğrencilerin Eysenck Kişilik Envanterinin alt boyutları (dışadönüklük, nevrotizm, psikotizm) ile Kişilerarası İlişki Tarzları Ölçeğinin alt boyutlarından (besleyici, zehirleyici) aldıkları puanlar arasında anlamlı derecede ilişkiler olduğu görülmektedir. Psikotik eğilim puanları ile zehirleyici ilişki tarzı puanları arasında ve dışadönük eğilim puanlarıyla besleyici ilişki puanları arasında pozitif yönde, anlamlı derecede ilişkiler olduğu; ayrıca nevrotik eğilim puanlarının da besleyici ilişki tarzı puanlarıyla negatif, zehirleyici ilişki tarzı puanlarıyla da pozitif yönde anlamlı ilişkili olduğu görülmektedir $(\mathrm{p}<0.01)$.

\section{Sonuç ve Tartışma}

Araştırmada, kullanılan ölçeklerden ve bu ölçeklerin alt testlerinden elde edilen puanlar araştırmanın bağımsız değişkenleri açısından incelenmiş bulgulara ulaşılmıştır.

Öğrencilerin cinsiyetlerine göre Eysenck Kişilik Envanterinin alt boyutlarından "dışadönüklük" alt boyutundan elde edilen ortalamalar açısından kızların erkeklere göre daha yüksek ortalamaya sahip oldukları ve cinsiyet açısından elde edilen bu farkın istatistiksel olarak anlamlı olduğu görülmüştür. Araştırma sonucunda dişadönüklük boyutunda erkekler lehine sonuçlar çıkması, toplumun erkeklerden beklediği erkeksi cinsiyet rolleri ile açılanabilir. Erkek çocuklarının genetik eğilimleri doğrultusunda, dışadönük, saldırgan davranışları erken yaşlardan itibaren pekiştirilirken, kız çocukların bu şekilde davranmaları toplumca hoş karşılanmamaktadır. Şahin ve Ünüvar (2010) tarafından Eğitim Fakültesi öğrencileri üzerinde yapılan bir araştırmada öğrencilerin dışadönüklük ve nevrotizm alt ölçeklerine ait puan ortalamaları arasında anlamlı bir faklılaşma görülmemesine rağmen Psikotizm puan ortalamalarının cinsiyete göre anlamlı şekilde farklılaştığı, erkeklerin kızlara göre daha psikotik özellikler gösterdiği gözlenmiştir. Deniz ve Kesicioğlu (2012) tarafından öğretmen adayları üzerinde yapılan bir araştırmada, kişilik ölçeğinin psikotizm, dışa dönüklük ve nörotizm alt boyularından aldıkları puan ortalamalarının 
cinsiyetleri açısından istatistiksel olarak anlamlı bir farklılık göstermediğini ancak dışa dönüklük puan ortalamalarının kız ve erkek öğrencilerde benzer olmasına karşın, psikotizm puanlarının erkeklerde, nörotizm puanlarının ise kız öğrencilerde daha yüksek olduğu bulgulanmıştır. Ulucan ve Bahadır (2011)'ın, sporcular üzerinde yaptıkları bir araştırmada sporcuların cinsiyetlerine göre Eysenck Kişilik Envanteri'nin dışa dönüklük alt boyutu boyutunda cinsiyet değişkenine göre anlamlı farklılık görülmememiş, ancak nevrotiklik alt boyutu boyutunda bayan sporcuların lehine anlamlı farklılıklar bulunmuştur. Shevlin ve ark. (2002)'nin yaptıkları bir araştırmada psikotizm puanlarının erkekler, nevrotizm puanlarının da kadınlar lehine anlamlı derecede farklılaştığı görülmüştür. Gazi Üniversitesi Beden Eğitimi Spor Yüksekokulu öğrencileri ile Gazi Üniversitesi Eğitim Fakültesi öğrencilerinin kişilik özelliklerinin incelendiği başka bir araştırmada (Akdoğan vd., 2007) nevrotiklik ve dışadönüklük alt boyutlarından elde edilen ortalamalar arasında cinsiyet değişkenine göre anlamlı farklılaşmalar bulgulanmıştır. Karancı, Dirik ve Yorulmaz (2007) tarafından üniversite öğrencileri üzerinde yaptıkları bir araştırmada öğrencilerin cinsiyet açısından; dişa dönüklük, nevrotizm ve psikotizm boyutlarında $\mathrm{k} ı$ ve erkekler arasında istatistiksel olarak anlamlı farklılaşmalar bulunmadığı saptanmıştır.

Araştırmada cinsiyete göre Kişiler Arası İlişki Tarzları ölçeğinden elde edilen ortalamalar arasında anlamlı bir farklılaşma olup olmadığına ilişkin sonuçlara bakıldığında alt ölçeklerden "zehirleyici ilişki" tarzları alt boyutundan elde edilen ortalamalar açısından bakıldığında; erkeklerin kızlara göre daha yüksek ortalamaya sahip olduğu ve cinsiyet açısından ortaya çıkan bu farkın istatistiksel olarak da anlamlı olduğu görülmektedir. Göçener (2010) tarafından üniversite öğrencileri üzerinde yapılan başka bir araştırmada kadınların ve erkeklerin kişilerarası ilişkiler toplam puanlarının kadınlar lehine, zehirleyici ilişki tarzları toplam puanlarının da erkekler lehine anlamlı derecede farklı bulunmuştur. İlgili araştırmalar incelendiğinde kişilerarası ilişki tarzlarının cinsiyete göre farklılaştı̆̆ını gösteren başka araştırma sonuçlarına (Erözkan, 2005, 2009; Sarı ve Aslan, 2005; Erözkan ve Yılmaz 2006; Aydın, 1993; Alkan,2008) da rastlanmaktadır.

Araştırmada, öğrencilerin öğrenim gördükleri bölümlere göre; Eysenck Kişilik Envanterinin alt boyutlarından "nevrotizm" alt boyutundan elde edilen ortalamalar açısından bakıldığında asında Türkçe Öğretmenliği bölümü öğrencilerine ait ortalamanın diğer bölüm öğrencilerinin ortalamalarından yüksek olduğu ve bu farkın istatistiksel olarak anlamlı olduğu görülmüştür. Şahin ve Ünüvar (2010) tarafından üniversite öğrencileri üzerinde yapılan başka bir araştırmada, psikotizm boyutunda; 
Türkçe ve Resim-Müzik öğretmenliği programlarında öğrenim gören öğrenciler lehine anlamlı derecede farklılaşmalar olduğu gözlenmiştir

Öğrencilerin öğrenim gördükleri bölümlere göre; Kişiler Arası İlişki Tarzları Ölçeğinin alt boyutlarından "zehirleyici ilişki tarzı" alt boyutundan elde edilen ortalamalar incelendiğinde Rehberlik ve Psikolojik Danışmanlık (PDR) bölümü öğrencilerine ait ortalamanın diğer bölüm öğrencilerine ait ortalamalardan anlamlı derecede yüksek olduğu görülmüştür.

Araştırmada, öğrencilerin öğrenim gördükleri sınıf düzeylerine göre Eysenck Kişilik Envanterinin alt boyutlarından "psikotizm" alt boyutundan elde edilen puanlar incelendiğinde; 3 . ve 4 . sinıf öğrencilerine ait ortalamaların 1. sınıf öğrencilerine ait ortalamadan anlamlı derecede yüksek olduğu görülmüştür. Şahin ve Ünüvar (2010) tarafından yapılan başka bir araştırmada da eğitim fakültesi öğrencilerinde Psikotizm, dışadönüklük, nevrotizm puan ortalamalarının 4.sınıflar lehine olduğu görülmüştür. Araştırmamızdan elde edilen bu paralel sonuç, öğretmen adaylarının kişilikleri üzerinde sınıf düzeyinin etkili olduğunu göstermektedir. Çünkü sınıf değişkeni genellikle yaş ile de ilgili bir değişkendir ve üniversiteye başlanılan yıl ile bitirilen yıllar arasında yaş ve deneyimlerin artmasına bağlı olarak değişim ortaya çıkabilir. Bazı araştırmalarda (Ulucan ve Bahadır, 2011; Deniz ve Kesicioğlu, 2012), öğrencilerin öğrenim gördükleri sinıf düzeyleri açısından psikotizm, nevrotizm ve dişadönüklük alt testlerinden elde edilen puanlar arasında anlamlı farklılaşmalar olmadığı görülmüştür.

Öğrencilerin öğrenim gördükleri sınıf düzeylerine göre Kişiler Arası İlişki Tarzları Ölçeğinin alt boyutlarından "zehirleyici ilişki tarzı" alt boyutundan elde edilen ortalamalar arasında 4 ssınıf öğrenciler yönünde anlamlı derecede farklılaşma olduğu görülmüştür. Zehirleyici ilişkiler, ilişki bozulduğunda ya da rakipler arasında kullanılan bir ilişki tarzı olarak görülen bir ilişki tarzıdır. 4. Sınıf öğrencileri arasında anlamlı derecede daha yüksek puanlarla görülmesi, üniversite yıllarının başlarında öğrencilerin daha çok sosyal desteğe ihtiyaç duymalarının sonucu olarak besleyici ilişki tarzının, 4.sınıfa geldiklerinde sosyal destekten ziyade bireyselliğin ön plana çıkması ile açıklanabilir Kişilerarası ilişki tarzlarının öğrencilerin öğrenim gördükleri sınıf düzeylerine göre farklılaşma gösterip göstermediklerinin incelendiği araştırmalarda (Erözkan, 2005, Yılmaz, 2007) sınıf düzeylerine göre anlamlı farklılaşmalara rastlanmıştır. Kişiler arası ilişki tarzlarına ilişkin, sınıf düzeyleri arasında yapılan karşılaştırmada (Erözkan, 2009) 4. sınıf öğrencilerinin diğer gruplara göre daha duyarlı ve daha dışadönük kişiler arası ilişki tarzlarına sahip oldukları görülmektedir.

Araştırmada, öğrencilerin algıladıkları gelir düzeyine göre Eysenck Kişilik Envanterinin alt boyutlarından "dışadönüklük" ve "psikotizm" alt 
Sosyal Bilimler Dergisi 73

boyutlarından elde edilen ortalamalar ve Kişiler Arası İlişki Tarzları Ölçeğinin alt boyutlarından "zehirleyici ilişki tarzı" alt boyutlarından elde edilen ortalamaların yüksek gelir düzeyinde algılayan gruplarda diğer gelir düzeyinde algılayan gruplara göre daha yüksek olduğu ve ortaya çıan bu farkın istatistiksel olarak anlamlı derecede olduğu görülmüştür. Konuyla ilgili literatür incelendiğinde bu araştırma sonucundan farklı olarak gelir düzeyi açısından gruplar arasında kişiler arası ilişki tarzlarının sosyoekonomik düzeyler açısından farklılaşma olmadığını gösteren araştırmalara da (Erzökan, 2009; Erözkan, 2005; Yılmaz, 2007) rastlanmaktadır.

Öğrencilerin, anne ve babalarının eğitim düzeylerine göre Eysenck Kişilik Envanterinin alt boyutlarından "psikotizm" alt boyutundan elde edilen ortalamalar incelendiğinde; annesinin eğitim düzeyi açıaından annesi üniversite mezunu olan öğrencilerle ilkokul mezunu olan öğrenciler arasında, babasının eğitim düzeyi açısından da bakıldığında babası üniversite mezunu olanlarla babası okuma yazma bilmeyenler arasında, anne-babası üniversite düzeyinde eğitimli olanlar yönünde olduğu görülmüştür. Eysenck ve Eysenck (1985) psikotizmin, psikoza ve psikopatolojiye genetik olarak eğilimli olmayı ifade ettiğini vurgulamaktadır. Buna paralel olarak anne ve babanın eğitim durumunun çocuğun psikolojik, sosyal ve zihinsel gelişim alanlarındaki etkisi yadsınamaz. Düşük eğitim düzeyinde olan anne-babaların, çocuk yetiştirme konusunda beklendiği gibi hatalı yetiştirme tarzları sergilemeleri söz konusudur. Ancak bu araştırmada, literatürden farklı olarak, hem anne hem de babanın eğitim düzeyinin yüksek olduğu öğrencilerde psikotizm eğilimi puanlarının yüksek çıkmış olması dikkat çekicidir. Veriler incelendiğinde her bir gruba ait psikotizm puanlarının minimum psikotizm puanlara yakın olduğu, ancak gruplar arasında böyle bir farkın olduğu görülmektedir. Bu araştırmada psikotizm puanları, her ne kadar anne ve babası üniversite mezunu öğrenciler yönünde çıkmış olsa da literatür incelendiğinde farklı bulgulara da rastlanmaktadır. Bu araştırma bulgularından farklı olarak, Deniz ve Kesicioğlu (2012) tarafından yapılan bir araştırmada, öğretmen adaylarının anne ve babalarının öğrenim düzeyleri ile psikotizm, nörotizm ve yalan alt boyutları arasında istatistiksel olarak anlamlı bir farklılık tespit edilememiştir. Aynı araştırmada öğretmen adaylarının annelerinin öğrenim düzeyleri ile kişilik ölçeğinin dışa dönüklük alt boyutu arasında anlamlı farklılık olduğu görülmüştür. Bu farkın kaynağı incelendiğinde üniversite mezunu anneler ile ilköğretim mezunu anneler arasında olduğu ve farkın üniversite mezunu anneler lehine olduğu saptanmıştır.

Öğrencilerin algıladıkları anne tutumlarına göre Eysenck Kişilik Envanterinin alt boyutlarından "dışadönüklük", "nevrotizm" alt 
boyutlarında ve Kişiler Arası İlişki Tarzları Ölçeğinin alt boyutlarından "zehirleyici ilişki tarzı" alt boyutundan elde edilen ortalamalar arasında anlamlı bir farklılaşma olduğu görülmüş̧ür. $\mathrm{Bu}$ farklılaşmanın "Dışadönüklük" alt boyutunda, annesinin tutumunu demokratik algılayan öğrencilerle, aşırı disiplinli algılayanlar arasında, annesini demokratik algilayanlar yönünde olduğu; "Nevrotizm" alt boyutunda ise annesinin tutumunu aşırı disiplinli algılayan öğrencilerle annesinin tutumunu demokratik algılayanlar arasında, aşırı disiplinli algılayanlar yönünde olduğu görülmüştür. Kişiler Arası İlişki Tarzları Ölçeğinin alt boyutlarından "zehirleyici ilişki tarzı" alt boyutunda görülen anlamlı farklılaşmanın da annesini gevşek tutumda algılayanlarla aşırı disiplinli algılayan öğrenciler arasında, gevşek tutumda algilayanlar yönünde olduğu görülmüştür. Annesinin Literatür incelendiğinde, anne-babanın reddedici tutumlarının nevrotizm puanları ile pozitif ilişkili olduğunu gösteren araştırmalara (Karanc1, Dirik ve Yorulmaz, 2007; Arrindell, Akkerman, Bages ve ark., 2005) rastlanmaktadır.

Öğrencilerin algıladıkları baba tutumlarına göre Eysenck Kişilik Envanterinin alt boyutlarından "dışadönüklük" alt boyutunda; en yüksek ortalamanın babasını demokratik algılayan öğrenciler olduğu, istatistiksel olarak anlamı farklılığın da babasını demokratik algılayanlarla aşırı disiplinli olanlar arasında olduğu görülmüştür. Öğrencilerin kişilerarası ilişki tarzları ölçeğinden elde ettikleri puan ortalamaları arasında algıladıkları baba tutumlarına göre anlamlı bir farklılaşma olmadığı görülmüştür. Ebeveyn tutumlarına göre kişilerarası ilişki tarzlarının farklılaşıp farklılaşmadığının incelendiği araştırma bulgularına da rastlanmaktadır Kişiler arası ilişki tarzlarına ilişkin, ebeveyn tutumlarına yönelik yapılan karşılaştırmada (Erözkan, 2009) gruplar arasında fark olmadığı görülmüştür.

Dışadönüklük puanlarının, anne ve babasını demokratik algılayan öğrencilerle aşırı disiplinli algılayanlar arasında, anne-babasının tutumunu demokratik algılayanlar yönünde yüksek çıkmış olması literatürle paralel bir sonuçtur. Erken yaşlardan itibaren çocuklarına aile içinde alınan kararlarda söz hakkı tanıyan aile yapılarında büyüyen çocukların kendilerini ifade etme konusunda daha dışadönük stratejiler kullandıkları görülmektedir. Yine aşırı disiplinli-baskıcı ebeveyn tutumlarının erken yaşlardan itibaren bağımsızlaşmaya, dolayısıyla kendini ifade etmeye engel olması bireyin ilerleyen dönemlerde nevrotik kişilik eğilimleri göstermesinde etkili olabilmektedir.

Sonuç olarak, araştırmada kullanılan Eysenck Kişilik Envanteri ve Kişiler Arası İlişki Tarzları Ölçeklerinin ve bu ölçeklere ait bazı alt ölçekler / 
alt boyutlarından elde edilen ortalama puanlar, öğretmen adaylarının cinsiyet, öğrenim gördükleri bölümler, sınıf düzeyi, algılanan gelir düzeyi, anneve babalarının eğitim düzeyleri, algıladıkları anne-ve baba tutumları açısından anlamlı derecede farklılaşmalar görüldüğü ancak öğretmen adaylarının aile bireyleri arasında sıklıkla psikolojik desteğe ihtiyacı olan birinin olup olmadığı, anne-babanın birlikte olup olmadığı değişkenlerine göre araştırmada kullanılan ölçekler ve bu ölçeklere ait alt ölçek / alt boyutlarından elde edilen puanlar arasında anlamlı farklılaşmalar olmadığ görülmüştür.

$\mathrm{Bu}$ araştırma sonucunda elde edilen bulgular ve yapılan tartışma sonucunda aşağıdaki önerilerde bulunulmuştur:

$\mathrm{Bu}$ araştırma eğitim fakültesi öğrencileri üzerinde yapılamış ve farklı bölümlerde eğitim gören öğrencilerin, ilişki tarzları ve kişilik eğilimleri açısından anlamlı derecede faklılaşmış oldukları görülmüştür. Bu konu, psiko-sosyal gelişim açısından çok önemli olan üniversite yıllarında olan diğer fakülte öğrencileri arasında da çalışılabilir.

Araştırmanın çalışma grubunda yer alan üniversite düzeyindeki öğrencilerinin ruhsal belirtileri arasında psikotizm ve nevrotizm eğilimlerinin yoğun olarak görülmesi zaman zaman psikolojik taramalar yapılması ve sonuçları hakkında profesyonel kişiler tarafından yardım sunulması psiko-sosyal gelişim ve ruhsal açıdan farkındalık kazanmaları anlamında yararlı olacağı önerilebilir.

\section{Kaynakça}

Akdoğan, S., Arslan, F., Bayraktar, G. (2007). Gazi Üniversitesi Beden Eğitimi ve Spor Yüksekokulu Öğrencileri ile Gazi Üniversitesi Eğitim Fakültesi Öğrencilerinin Cinsiyet Değişkenine Göre Kişilik Özelliklerinin İncelenmesi. Çukurova Üniversitesi 5. Ulusal Beden Eğitimi ve Spor Öğretmenliği Sempozyumu, Adana.

Alkan E (2008). Cinsel İşlev Bozuklukları ve Kişilerarası Tarz, Öfke, Kendilik Algısı. Yüksek Lisans Tezi, Ankara Üniversitesi Sosyal Bilimler Enstitüsü.

Arrindell WA, Akkerman A, Bages N ve ark. (2005). The short-EMBU in Australia, Spain, and Venezuela. Europe Journalof Psychological Assessment, 21: 56-66

Aydın, A. (1996) Empatik Becerinin Çeşitli Değişkenler Açısından İncelenmesi. Yayınlanmamış Yüksek Lisans Tezi, Ege Üniversitesi.

Aydın, G. (1993). İç-dış Kontrol Odağı İnancı ile Durumluk Mizah Tepkisi Arasındaki İlişki. II. Ulusal Psikolojik Danışma ve Rehberlik Kongresi, Hacettepe Üniversitesi, Ankara. 
Bektaş Çağlar, S., Yazıcı, Hikmet ve Altun, F. (2013). Öğretmenlerin Kişilik Özellikleri ve Kişisel Sağlık Davranışları ile Depresif Belirtileri Arasındaki İlişkiler. Atatürk Üniversitesi Sosyal Bilimler Enstitüsü Dergisi 201317 (1): 127-141

Child, I.L. (1968). Personality in culture. E. F. Borgatta \& W.W. Lambert (Eds.), Handbooks of personality theory and research. Chicago: Rand McNally.

Cüceloğlu, D. 1997, İnsan ve Davranışı: Psikolojinin Temel Kuramları, Remzi Kitapevi, İstanbul.

Deniz, Ü. ve Kesicioğlu, O.S.(2012) Okul Öncesi Öğretmen Adaylarının Kişilik Özelliklerinin Bazı Değişkenlerle İlişkisinin İncelenmesi. Ahi Evran Üniversitesi Kırşehir Eğitim Fakültesi Dergisi (KEFAD) Cilt 13, Sayı 2, A ğustos 2012, Sayfa 1-13

Erözkan, A. (2005). Üniversite Öğrencilerinin İletişim Becerilerini Etkileyen Faktörler. VIII. Ulusal Psikolojik Danışma ve Rehberlik Kongresi, Marmara Üniversitesi, İstanbul.

Erözkan, A. (2009). Üniversite öğrencilerinin kişiler arası ilişki tarzları ve mizah Tarzları, Dokuz Eylül Üniversitesi Buca Eğitim Fakültesi Dergisi 26

Erözkan, A. ve Yılmaz, B. (2006). Üniversite Öğrencilerinin Mizah Tarzları ve Bağlanma Stilleri. XV. Ulusal Ĕ̆itim Bilimleri Kongresi, Muğla Üniversitesi, Muğla.

Eysenck H.J., Eysenck S.B. (1964) Manual of the Eysenck Personality Inventory. University of London Press, London.

Eysenck H.J., Eysenck S.B. (1968) The measurement of psychoticism: a study of factor stability and reliability. Br J Soc Clin Psychol, 7: 286-294.

Eysenck H.J., Eysenck S.B. (1975) Manual of the Eysenck Personality Questionnaire (adult and junior). Hodder \& Stoughton, London.

Goodworth, C. (1988). The Secrets Of Succesful Leadership And People Management. London: Heinemann Pub.Ltd.

Göçener, D. (2010). Üniversite Öğrencilerinin Güvenli Bağlanma Düzeyleri İle Kişilerarası İlişki Tarzları Arasındaki İlişkiler. Yüksek Lisans Tezi Ankara Üniversitesi, Sosyal Bilimler Enstitüsü, Psikoloji (Sosyal Psikoloji) Anabilim Dalı, Ankara.

Greenwald, J. (1999). Bağımlılık mı? Bağlılık mı? Zehirleyici İlişkilerden Besleyici İlişkilere, Zeynep Yıldırımoğlu (çev.). İstanbul: Kuraldışı.

Hamarta, E. (2002). Bağlanma Teorisi ve Yetişkin İlişkilerinde Bağlanma. Ĕ̆itime Yeni Bakışlar-I, (Ed.) A.M. Sünbül. Ankara: Mikro.

Hasta, D. ve Güler, M. E. (2013). Saldırganlık: Kişilerarası İlişki Tarzları ve Empati Açısından Bir İnceleme. Ankara Üniversitesi Sosyal Bilimler 
Sosyal Bilimler Dergisi 77

Enstitüsü Dergisi, 4 (1).

Henjum, A. (1983). Introversion: a misunderstood "individual difference" among students. Education, 103(1), 39-43.

İnanç, Y.B ve Yerlikaya, E.E (2008). Kişilik Kuramları, Pegem Akademi Yayınları, Ankara.

Karancı, N., Dirik, G. ve Yorulmaz O. (2007). Eysenck Kişilik Anketi-Gözden Geçirilmiş Kısa Formu'nun (EKA-GGK) Türkiyede Geçerlik ve Güvenirlik çalışması, Türk Psikiyatri Dergisi, 18 (3),1-8.

Kiesler, D. J. (1983). The 1982 Interpersonal circle: A taxonomy for complementarity in human transactions. Psychological Review, 90, 185-214.

Leary, T. (1957). Interpersonal diagnosis of personality. New York: The Ronald Press Company. Lopez

Lewis C.A., Francis LJ, Shevlin M ve ark. (2002) Confirmatory factor analysis of the French translation of the abbreviated form of the Revised Eysenck Personality Questionnaire (EPQR-A). Europe J Psychol Assess, 18: 7985.

Öner, N. (1997). Türkiye'de Kullanılan Psikolojik Testler. Boğaziçi Üniversitesi Yayınevi, 3. Basım, İstanbul

Öztan, N. (1996). Kişilerarası İlişkiler Tarz Ölçeği ve Güvenirliği: Bir Ön Çalışma. VIII. Ulusal Psikoloji Kongresi Bilimsel Çalışmaları, 21-23 Eylül 1994 İzmir. Yurdal Topsever ve Melek Göregenli (Ed.). Ankara: Türk Psikologlar Derneği Yayınları.

Pişkin, M. (2004). İçedönük ve Dışadönük Kişilik Yapısı (Editörler Yıldız Kuzgun, Deniz Deryakulu) Eğitimde bireysel farklılıklar, Ankara, Nobel Yayın Dağıtım.

Plutchik, R. (1997). The circumplex as a general model of the structure of emotions and personality. Plutchik, R. ve Conte, R. H. (Eds.), Circumplex models of personality and emotions . USA: American Psychological Association Press.

Sarı, T. ve Aslan, H. (2005). Mizah Tarzları ve Başaçıkma Stratejileri Arasındaki İlişki. VIII. Ulusal Psikolojik Danışma ve Rehberlik Kongresi, Marmara Üniversitesi, İstanbul.

Savaşır, I. ve N. H. Şahin (Ed.). (1997). Bilişsel-Davranışçı Terapilerde Değerlendirme: Sık Kullanılan Ölçekler. Ankara: Türk Psikologlar Derneği.

Savran, C. (1993). Sıfat Listesinin (Acl) Türkiye Koşullarına Uygun Dilsel Eşdeğerlilik, Geçerlilik, Güvenirlilik, Norm Çalışması ve Örnek Bir Uygulama. Yayınlanmamış Doktora Tezi. Marmara Üniversitesi, Sosyal Bilimler Enstitüsü, Eğitim Bilimleri Anabilim Dalı. İstanbul. 
Shevlin, M., Bailey F. \& Adamson, G. (2002). Examining the factor structure and sources of differential functioning of the Eysenck Personality Questionnaire Revised-Abbreviated. Pers Individ Dif, 32:479-487

Sullivan, H.S. (1953). The Interpersonal Theory of Psychiatry, New York: Norton.

Şahin N, Durak A, Yasak Y. (1994). Interpersonal style, lone-liness and depression. 23rdInternational Congress of Applied Psyclology (July 1722, Madrid), 1994.

Şahin, H. ve Ünüvar, P.(2010) Eğitim Fakültesi Öğrencilerinin Empatik Becerileri Ve Kişilik Özelliklerinin İncelenmesi. 19.Eğitim Bilimleri Kongresi. Mehmet Akif Ersoy Üniversitesi, Burdur, Türkiye

Şahin, N. H., Batıgün, A. D. ve Koç, V. (2011). Kişilerarası Tarz, Kendilik Alg1sı, Öfke ve Depresyon. Türk Psikiyatri Dergisi, 22 (1), 17-25.

Şahin, N. H., Durak, A. ve Yasak, Y. (1994). Kişilerarası İlişkiler Ölçeği. VIII. Ulusal Psikoloji Kongresi Bilimsel Çalışmaları, İzmir 21-23 Eylül.

Şahin, N.H., Batıgün, A.D. ve Koç, V. (2011) Kişilerarası Tarz, Kendilik Alg1s1, Öfke ve Depresyon. Türk Psikiyatri Dergisi 2011;22(1):17-25

Tokgöz, G. (1997). Kişilik Bozuklukları ile İçedönüklük-Dışadönüklük Değişkeni Arasındaki İlişki. Yayınlanmamış Yüksek Lisans Tezi, İstanbul Üniversitesi, Sosyal Bilimler Enstitüsü, İstanbul.

Topçu S. (1982) Çocuk ve yetişkinlerde kişilik boyutları ile bu boyutlarda kültürler-arası ayrılıklar. Yayınlanmamış doçentlik tezi, Hacettepe Üniversitesi: Ankara.

Tutkun, E., Güner, B. Ç., Ağaoğlu, S. A. ve Soslu, R. (2010). Takım Sporları ve Bireysel Sporlar Yapan Sporcuların Saldırganlık Düzeylerinin Değerlendirilmesi. Spor ve Performans Araştırmaları Dergisi, 1 (1), 23-29.

Ulucan, H., Bahadır, Z. (2011). Haltercilerin Kişilik Özelliklerinin Farklı Değişkenlere Göre İncelenmesi, Niğde Üniversitesi Beden Eğitimi Ve Spor Bilimleri Dergisi Cilt 5, Sayı 2.

Yanbastı, G. 1990. Kişilik Kuramları, Ege Üniversitesi Basımevi, İzmir

Yildız, M. 2009, Amatör ve Paf Liginde Oynayan Futbolcuların Kişilik Tipleri ve Sürekli Öfke-Öfke İfade Tarzlarının İncelenmesi. Atatürk Üniversitesi, Beden eğitimi ve Spor Bölümü Dergisi, 11 (3), 15-27, Erzurum

Yılmaz, B. (2007). “Üniversite Öğrencilerinin Kişiler arası İletişim Becerileri ve Bağlanma Stilleri Arasındaki İlişki" Yayımlanmamış Yüksek Lisans Tezi, Muğla Üniversitesi SBE.

Yüksel, Ö. (2006). Davranış Bilimleri. Ankara: Gazi Kitapevi. 